\title{
Analysis of Direct Budget Implementation Building Construction Work
}

\author{
Anita Rauzana \\ (Staff of Civil Engineering Department, University of Syiah Kuala, Banda Aceh, Indonesia)
}

\begin{abstract}
The study entitled "Analysis of Direct Budget Implementation Building Construction Work" aims to compare the direct costs of implementation of the work in the field with the cost of the contract. Because of differences in costs in the field with the cost of the contract, it can affect the size of the benefits obtained from the executor. Which is the object in this paper is the allocation of direct costs for materials, wages and equipment. To support the calculation of the data required at the time of implementation, which consists of primary data and secondary data, the scope of work is reviewed in this study is the work of the foundation, plinth, columns and walls. Observation of the direct costs of research and calculation begins at the time of entry, use, and installation of materials and labor used much every day. While the calculation of the budget in the contract for the cost of resources is calculated by using analysis of BOW. From the calculation results obtained by the direct costs of implementation for the scope of work to be a review is Rp.211,771,639 while the amount of the contract budget is Rp.320, 342.678 to the difference in cost is Rp.108,571,039 or 33.89\%.
\end{abstract}

Keywords: direct costs, materials, labor, equipment, cost of contract

\section{Introduction}

In a project cost of use is strongly influenced by the use and management of resources by both skilled in the art to manage any resources used. At the implementation stage will be the cost difference between the costs of implementing to contract cost. These differences greatly affect the size of the profit earned by the executor, and then the problem that arises is how to calculate and analyze the cost of the contract with the implementation of cost in the field. To find out the direct costs that occurred in the implementation of the work done by direct observation in the field, from which the data obtained about the amount of material, number / type of employment and type of equipment used at the time of execution, while the budget for the contract, for the cost of resources is calculated analysis using BOW. Objectives to be achieved in this paper are to compare the direct costs of implementation of the work in the field at a cost that is in the contract.

The data used to calculate the direct costs consist of primary data is data obtained from direct observation in the field. The primary data consists of data obtained materials, equipment data, employment data and time data based on the implementation of workforce skills. Other data used are secondary data is data obtained from executor the project.

The scope of work to be reviewed at the building project is just a limit on the foundation work, plinth, columns, and walls to look for the calculation of the direct costs of implementation. The results of this study is expected to be useful as an information and reference for decision makers in the planning and budget as a guideline to create a method of execution in the perform and determine the resource settings at the time of implementation in the future.

\section{Literature Review}

Cost calculation is the process of calculating the volume of work, the price of various materials, equipment, labor and employment that occurred in a construction. Direct costs are costs for things that will become a permanent component of the project outcomes and indirect costs are expenditures for management, supervision, and payment for the procurement of materials and services that are not part of the project will be a permanent installation or product [8]. Cost is an important part in the implementation of the development. The use of costs in a job should be taken into account and properly managed so that the budget needed to be economical [3]. Costs are the expenses for the operation of the project implementation, installation and maintenance of project outcomes [7]. To know the magnitude of the direct costs of implementing a budget work done recalculate the costs required for each resource used in the field at the time of execution. that there are some key things to note in the calculation of costs [6], namely

1. Material, calculate the amount of material used according to the type and amount of the fee.

2. Labor, calculate the amount of labor used in qualifying and the amount of the fee.

3. Equipment, counting the number of equipment used by type and amount of the fee.

4. Over head, namely unexpected expenses that needs to be held.

5. Profit, namely benefits to be obtained. 


\subsection{Materials}

Material cost is the cost of everything of a substantial nature that is essential to the construction or operation of a facility, both of a direct or indirect nature [1]. For the price of materials based on local prices, so it includes the cost of freight, the cost of raising and lowering costs [6]. The budget material usage (in the unit and the cost of usage) is made on the basis of standard cost systems (in particular, the number of units required for the direct cost of producing one unit of finished goods) [5]. Analysis of BOW is a source of a formula determining the unit price of each type of work. Each type of work included analytical index, which consists of two groups of numbers (coefficient) is the fractional (unit number) for the material and the fractions (unit rate) to pay [4]. To calculate the type and amount of material used is calculated using the formula:

$C=A i x b$

where: $C=$ material costs $(R p / p c s)$

$A i=$ material unit price $(R p / p c s)$

$b=$ number of materials (trucks, rods, zak, sheet)

$i=$ type of material

\subsection{Equipments}

Implementation of the work on a project using different types of equipment is adjusted according to the type and volume of work. The contractor who will handle the job with great cost and volume and nature of the job involves so much construction equipment, it must determine the procurement of equipment were rented or purchased [7]. Type of equipment used can be classified into two types, namely equipment and tools. Type of equipment the cost of equipment is calculated from the number of days based on usage of equipment rental per day, can be calculated by the formula:

$B s=J_{s} \times H s$

Where : Bs $=$ cost of equipment rental $(R p /$ day)

$J_{s}=$ number of days of use (days)

$H s=$ price per day equipment rental $(R p /$ day $)$

Equipment with the type of tool is calculated based on the amount of equipment used and the purchase price by type can be calculated by the formula:

$B p=J p \times H p$

Where: $B p=$ Equipment cost $(R p / p c s)$

$J p=$ Number of equipment $(p c s)$

$\mathrm{Hp}=$ equipment unit price $(\mathrm{Rp} / \mathrm{pcs})$

\subsection{Labor}

Labor costs are Gross direct wages paid to the worker, plus labor burden, plus field indirects, plus general \& administrative cost, plus profit [1]. The amount of labor used to be arranged in such a way, this is done to avoid waste of labor that affect the cost. The workforce is one of the important resources, and then these resources should be used efficiently [10]. To calculate the labor costs in finishing a job type, then it can be done to the formula:

$U p=\operatorname{Jp} \times D \times U s$

Where $: U p=$ The cost of labor costs $(R p /$ day)

$J p=$ Number of labor used (people)

$D=$ the completion time of a job (days)

Us = Price unit labor costs (Rp / day)

\subsection{Method of Implementation}

Method of implementation is necessary for the smooth implementation of the work to the implementation of time management, labor, materials and equipment used to achieve high productivity and can eventually result in a budget implementation costs are relatively inexpensive [2]. To create a method of execution of job retention, need to know situation the job site so that arrangements can be made against any resources used.

\section{Research Methodology}

The research was conducted in the morning and afternoon, observations were made during an average work began at 08.00 am to $18.00 \mathrm{pm}$ for 77 days. The scope of work under review is limited to implementation; foundation works, plinth works, column works and the works of the wall. The data used were obtained from observations in the field at the time of execution of work in progress, consists of primary data; data on building materials, equipment used in the field., Data on labor, and data on the execution time and data on the volume of 
work. While other data obtained from implementing the project called secondary data consisting of: data on the work plan and any other terms, drawing plans, detail drawings, construction drawings pieces, this data is useful to compare the volume of work in the field with the volume of work on the contract.

To determine the amount of material, labor and equipment cost analysis performed directly on the field, as for the analysis include:

a. Calculate the volume of work in the field, by measuring back every job that the object of thereview and described again in order to get the actual volume of work.

b. Determine the number and amount of material used and the amount of labor used.

c. Amount of material usage and labor of the whole activity, each unit price multiplied by the local and specific to the wages of labor multiplied according to the amount of wages paid each of the workforce.

d. Determine the number and type of equipment usage and the amount of the rent / buy

e. Further comparison is made between the price obtained in the field with prices in the contract. Comparisons were made to the respective percentage of direct costs.

\subsection{Volume of Work in the Field}

\section{Results And Discussion}

Volume of work is very influential in the use of resources in the field. The greater the volume of work the greater the resources used. Of calculating the volume of work in the field there are differences in the volume of works in the field and in the contract. More detail can be seen in Table 4.1 below.

Table 4.1 comparison of the volume of work in contract and in the field

\begin{tabular}{|c|c|c|c|c|}
\hline \multirow{2}{*}{$\begin{array}{l}\text { JOB DESCRIPTION } \\
\text { WORK MINING }\end{array}$} & \multicolumn{2}{|c|}{$\begin{array}{l}\text { Volum Of Works } \\
\text { in Contracts }\end{array}$} & \multicolumn{2}{|c|}{$\begin{array}{c}\text { Volume of } \\
\text { Works in the } \\
\text { Field }\end{array}$} \\
\hline & & & & \\
\hline 1. Pit foundation Tread & 50 & $\mathrm{~m} 3$ & 90 & $\mathrm{~m} 3$ \\
\hline 2. Pit Land Foundation & 30.31 & $\mathrm{~m} 3$ & 27.9 & $\mathrm{~m} 3$ \\
\hline 3. Heaps Back Former Pit & 49.79 & $\mathrm{~m} 3$ & 45.87 & $\mathrm{~m} 3$ \\
\hline $\begin{array}{l}\text { 4. Under Floor Heating Soil } \\
\text { Heaps }\end{array}$ & 359.75 & $\mathrm{~m} 3$ & 271.75 & $\mathrm{~m} 3$ \\
\hline $\begin{array}{l}\text { 5. Heaps of Land Down the } \\
\text { hall floor }\end{array}$ & 177.29 & $\mathrm{~m} 3$ & 82.95 & $\mathrm{~m} 3$ \\
\hline 6. Heaps Sand Floor Heating & 55.78 & $\mathrm{~m} 3$ & 51.98 & $\mathrm{~m} 3$ \\
\hline 7. Alas Foundation Sand & 41.23 & $\mathrm{~m} 3$ & 20.23 & $\mathrm{~m} 3$ \\
\hline $\begin{array}{l}\text { 8. Alas Foundation } \\
\text { Continuous Sand }\end{array}$ & 32.72 & $\mathrm{~m} 3$ & 22.12 & $\mathrm{~m} 3$ \\
\hline \multicolumn{5}{|l|}{$\begin{array}{c}\text { PAIR OF \& CONCRETE } \\
\text { WORK }\end{array}$} \\
\hline \multicolumn{5}{|l|}{ 1. First Floor Works } \\
\hline 2. Empty Stone Aanstamping & 41.25 & $\mathrm{~m} 3$ & 35.78 & $\mathrm{~m} 3$ \\
\hline 3. Pair Stone Mountain & 50 & $\mathrm{~m} 2$ & 68.78 & $\mathrm{~m} 2$ \\
\hline 4. Pair Trasram Bricks $(1: 2)$ & 321.5 & $\mathrm{~m} 2$ & 101.51 & $\mathrm{~m} 2$ \\
\hline 5. Pair Bricks $(1: 4)$ & 789.12 & $\mathrm{~m} 2$ & 502.22 & $\mathrm{~m} 2$ \\
\hline 6. Bricks Trasram Plastering $(1: 2)$ & 412.31 & $\mathrm{~m} 2$ & 187 & $\mathrm{~m} 2$ \\
\hline 7. Plastering Bricks $(1: 4)$ & 1577.79 & $\mathrm{~m} 2$ & 710.79 & $\mathrm{~m} 2$ \\
\hline \multicolumn{5}{|l|}{ 8. Reinforced Concrete } \\
\hline - Column 35/40 & 31.42 & $\mathrm{~m} 3$ & 20.56 & $\mathrm{~m} 3$ \\
\hline - Plinth 25/35 & 15 & $\mathrm{~m} 3$ & 20.12 & $\mathrm{~m} 3$ \\
\hline - The foundation & 30.57 & $\mathrm{~m} 3$ & 25.66 & $\mathrm{~m} 3$ \\
\hline
\end{tabular}

Table 4.1 comparison of the volume of work on the contract and the volume of work in the field look a difference, a difference occurs because the volume calculation results in the field are not consistent with the volume of work on the contract or an error in the drawing on the contract, and therefore the volume in the field does not match with the volume in drawing on the contract. 


\subsection{The Cost of Material}

The amount of costs of materials based on the results of the calculation is Rp. 184,102,275 or $87.00 \%$ of total direct costs for the scope of work to be review. While the cost of materials in the contract amount of Rp. $232,544,613$ or $73.00 \%$ of the total contract cost for the scope of the review. Amount of the cost of materials used for each type of work can be seen in Table 4.2 as follows.

Table 4. 2 Total cost of materials

\begin{tabular}{|l|l|l|}
\hline \multicolumn{1}{|c|}{ Description of Activities } & \multicolumn{1}{c|}{$\begin{array}{c}\text { Field Cost } \\
\text { (Rupiah) }\end{array}$} & \multicolumn{1}{|c|}{$\begin{array}{c}\text { Contract Cost } \\
\text { (Rupiah) }\end{array}$} \\
\hline $1 . \quad$ Groundwork & \multicolumn{1}{c|}{} \\
\hline$-\quad$ Soil & $10,000,000$ & $18,563,904$ \\
\hline$-\quad$ Sand & $7,500,000$ & $3,859,548$ \\
\hline $2 . \quad$ Couple and plastering jobs & & \\
\hline$-\quad$ Stone Mountain & $10,821,000$ & $28,031,870$ \\
\hline$-\quad$ Bricks & $17,210,000$ & $26,847,181$ \\
\hline$-\quad$ Cement & $35,320,000$ & $34,104,277$ \\
\hline$-\quad$ Sand & $14,500,775$ & $22,990,401$ \\
\hline $3 . \quad$ Concrete mold & & \\
\hline$-\quad$ Wood & $1,500,000$ & $4,314,032$ \\
\hline$-\quad$ Board & 750,500 & $3,053,280$ \\
\hline$-\quad$ Nails & $2,500,000$ & $5,152,664$ \\
\hline $4 . \quad$ Steel Works & & \\
\hline$-\quad$ Iron & $60,000,000$ & $50,979,700$ \\
\hline$-\quad$ Wire fastening & $1,500,000$ & $1,144,980$ \\
\hline $5 . \quad$ Foundry jobs & & \\
\hline$-\quad$ Cement & $8,000,000$ & $15,139,180$ \\
\hline$-\quad$ Sand & $6,500,000$ & $6,233,933$ \\
\hline$-\quad$ Gravel & $8,000,000$ & $12,129,663$ \\
\hline$\quad$ TOTAL & $184,102,275$ & $232,544,613$ \\
\hline
\end{tabular}

From the results of Table 4.2 shows that the use of pricing the use of the cheapest on the work under review is the price based on observations in the field. As for the cause in question is the price difference due to the volume of work in a field different from the volume of work on the contract as well as differences in unit prices of these materials, such as for soil piled on the contract price per cubic meter is taken in the field, while in the contract the price per truck is taken, or to steel is taken in the contract price in per $\mathrm{kg}$, while in the field made the price in per stem, to the difference in this unit, then there is the cost difference between the contract cost and the field cost, where the cost of in the field is cheaper than the cost of the contract. Before work begin, all the necessary ingredients already in the field before starting the installation job retention.

\subsection{The Cost of Equipment}

Calculation results obtained from the cost of equipment used for this type of work that is reviewed is Rp. $4,547,000$ or $2 \%$ of the total direct costs for the scope of work to review. Total costs according to the type of equipment used in this project can be seen in Table 4.3 below.

Table 4.3 cost of equipment according to the type

\begin{tabular}{|ll|l|}
\hline Types of equipment & \multicolumn{1}{c|}{$\begin{array}{c}\text { Total cost } \\
\text { (Rupiah) }\end{array}$} \\
\hline $1 . \quad$ Hoes & 155,000 \\
\hline $2 . \quad$ Scope & 77,000 \\
\hline $3 . \quad$ Bucket & 65,000 \\
\hline $4 . \quad$ Wheelbarrow & 750,000 \\
\hline $5 . \quad$ Molen & $3,500,000$ \\
\hline TOTAL & $4,547,000$ \\
\hline
\end{tabular}

From the above Table 4.3 is based on the use of equipment in the field obtained at a lower price than the cost calculations contained in the contract, this happens because the equipment used on one type of work can also be 
used on other jobs, so that purchases can be done only once before required the addition. Equipment used during the implementation tailored to the needs of the job. Equipment used during the implementation is divided into two types, namely type of equipment and tools. Equipment used is cement mixer for foundry work, cement mixer for foundry work used in this project is a day of equipment rent from others.

\subsection{The Cost of Labor}

Based on the calculation of the overall labor cost is Rp. $23,122,364$ or $11.00 \%$ of total direct costs for the implementation of the scope of the work reviewed. While the cost of labor in contract is Rp.87,798,065 or $27.00 \%$ of the total contract cost for the scope of the work reviewed. The amount of labor costs for each type of work can be seen in Table 4.4 below.

Table 4. 4 Total cost of labor

\begin{tabular}{|c|c|c|}
\hline Types of Work & $\begin{array}{l}\text { Total costs in the field } \\
\text { (Rupiah) }\end{array}$ & $\begin{array}{l}\text { Total costs in the Contract } \\
\text { (Rupiah) }\end{array}$ \\
\hline \multicolumn{3}{|l|}{ 1. Groundwork } \\
\hline - Labor & $2,600,000$ & $7,900,567$ \\
\hline - $\quad$ Head of builders & 777,000 & 550,890 \\
\hline - $\quad$ Mandor & & $12,980,000$ \\
\hline \multicolumn{3}{|c|}{ 2.Installation and plastering jobs } \\
\hline - Labor & $4,122,364$ & $10,089,096$ \\
\hline - $\quad$ Head of builders & $1,422,000$ & $9,095,674$ \\
\hline - $\quad$ builders & $4,626,000$ & $5,608,790$ \\
\hline - $\quad$ Mandor & & $9,456,765$ \\
\hline \multicolumn{3}{|l|}{ 3. Iron Works } \\
\hline - $\quad$ Labor & $2,700,000$ & $9,876,765$ \\
\hline - $\quad$ builders & $1,050,000$ & $7,923,567$ \\
\hline - $\quad$ Head of builders & $1,500,000$ & 357,489 \\
\hline \multicolumn{3}{|l|}{ 4. Concrete mold } \\
\hline - Labor & 900,000 & 702,873 \\
\hline - $\quad$ builders & 269,000 & 101,987 \\
\hline - $\quad$ Head of builders & 440,000 & 43,073 \\
\hline - $\quad$ Mandor & & $9,789,654$ \\
\hline \multicolumn{3}{|l|}{ 5. Foundry jobs } \\
\hline - Labor & $1,890,000$ & $1,985,123$ \\
\hline - $\quad$ builders & 276,000 & 546,098 \\
\hline - $\quad$ Head of builders & 550,000 & 789,654 \\
\hline \multicolumn{3}{|l|}{ - $\quad$ Mandor } \\
\hline TOTAL & $23,122,364$ & $87,798,065$ \\
\hline
\end{tabular}

From the calculation of the cost of the use of labor based on the observation in the field shows that the cost of labor is lower than the amount of labor costs in the contract. Where these are due to the large amount of labor in the contract is different from that applied in the field. The use of labor in the field prioritizes the sources closest to the location of the work, this is done to empower existing resources around the project as well as regional wages. The amount of labor used for a different type of work to another type of work, depending on the needs and volume of work. Here the necessary expertise and experience of the implementers in regulating the amount of labor used for any type of work. Wages are paid on a daily wage. The wage payment is calculated per working day with the unit in accordance with the wage set by the authorities for regional wages.

\subsection{The cost of direct execution}

The magnitude of the direct cost of the overall implementation cost over head outside the scope of work for which a review in this paper based on the calculation is as follows: for the material cost of Rp. $184,102,275$ or $(87.00 \%)$, equipment costs Rp. $4,547,000$ or (2.00\%) and for the labor cost of Rp. 23,122,364 or (11.00\%). The magnitude of the direct costs of implementation that consists of the cost of materials, labor and equipment amounting to Rp. 211,771,639, while the overall cost of the contract amounts to Rp. 320,342,678. The number of direct costs of this implementation is smaller than the direct cost budget is in the contract budget 
plan, with the difference in cost is Rp. 108,571,039 or $33.89 \%$ for the scope of the work reviewed. This difference occurs because of differences in resource use in the field at the time of execution of work. To get the direct costs of implementation required an economical and good management of all resources used during the execution of field work in progress. This is done to avoid the wasteful use of resources will affect the cost. Obtained from the difference in cost is the cost of the benefits of implementing the project before plus taxes and over head.

\section{Conclusion}

1. Direct costs of physical work for the implementation of the scope of work to be review the project amounting to Rp. 211,771,639 and contract costs amounting to Rp.320, 342.678 with the difference in the cost of Rp. 108,571,039 or 33.89\%.

2. Direct cost of resources used in this project based on scope of work under review is the material costs amounting to Rp. $184,102,275$ or $(87.00 \%)$, equipment costs amounting to Rp. $4,547,000$ or $(2.00 \%)$ and labor costs amounting to Rp. 23,122,364 or (11.00\%). While the material costs in the contract document is Rp. $232,544,613$ or $73.00 \%$ and labor costs amounting to Rp. $87,798,065$ or $27.00 \%$ of the total contract cost for the scope of the work reviewed.

1. Coefficient value of labor used in the analysis of the cost of the contract on this project is too large when compared to those used at the time of execution. This is evidenced by the difference in labor costs that occur based on the results of the comparison between both costs.

2. Volume of work in the field is not equal to the volume of work in the contract.

\section{References:}

[1] AACE International. Cost engineering terminology (Recommended practice 10S-90, Morgantown, W.Va. 2007)

[2] B. Husin, Quantity and Evaluation (Faculty of Engineering Unsyiah, Banda Aceh. 1987)

[3] J.A. Mukomuko, Budgeting Basics Building Costs (CV. Media Gaya Pratama, Jakarta. 1985).

[4] Niron, Building Budget Planning (Jakarta : Rembulan. 1980)

[5] Ralph, Cost Accounting 2 (Jakarta, Gunung Tuan.1984)

[6] A.S. Soedrajat, The Budget Cost Analysis Building (Bandung :Nova.1984)

[7] Soeharto, Project Management ( Jakarta :Erlangga. 1999)

[8] Soeharto, Project Management (Jakarta : Erlangga. 1997) 